This item was submitted to Loughborough's Research Repository by the author.

Items in Figshare are protected by copyright, with all rights reserved, unless otherwise indicated.

\title{
Production of porous silica microparticles by membrane emulsification
}

PLEASE CITE THE PUBLISHED VERSION

http://dx.doi.org/10.1021/la202974b

\section{PUBLISHER}

(C) American Chemical Society

\section{VERSION}

AM (Accepted Manuscript)

\section{LICENCE}

CC BY-NC-ND 4.0

\section{REPOSITORY RECORD}

Dragosavac, Marijana M., Goran T. Vladisavljevic, R.G. Holdich, and Michael T. Stillwell. 2012. "Production of Porous Silica Microparticles by Membrane Emulsification". figshare. https://hdl.handle.net/2134/9368. 
This item was submitted to Loughborough's Institutional Repository (https://dspace.lboro.ac.uk/) by the author and is made available under the following Creative Commons Licence conditions.

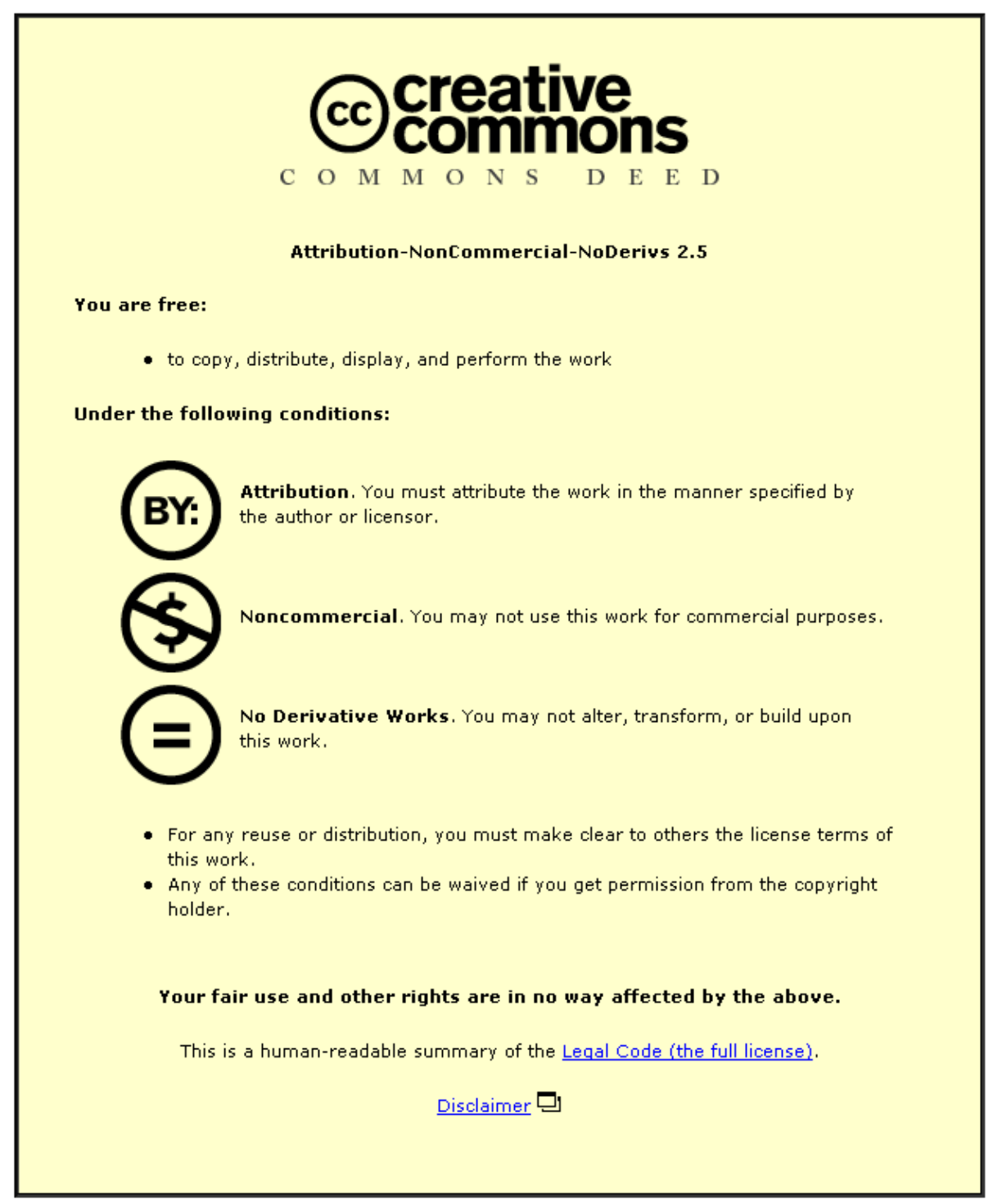

For the full text of this licence, please go to: http://creativecommons.org/licenses/by-nc-nd/2.5/ 


\section{Production of porous silica microparticles by}

\section{membrane emulsification}

Marijana M. Dragosavac ${ }^{1 *}$, Goran T. Vladisavljevic ${ }^{1,2}$, Richard G. Holdich ${ }^{1,3}$ and Michael T. Stillwell ${ }^{3}$

${ }^{1}$ Chemical Engineering Department, Loughborough University, Loughborough, Leicestershire LE11 3TU, UK

${ }^{2}$ Vinča Institute of Nuclear Sciences, PO Box 522, Belgrade, Serbia

${ }^{3}$ Micropore Technologies Ltd., Hatton, Derbyshire, DE65 5DU, UK

"Corresponding author's address:

Marijana M. Dragosavac, Department of Chemical Engineering, Loughborough University, Loughborough, Leicestershire, LE11 3TU, UK. Tel: +44 1509 564094, Fax: +44 1509 223923, e-mail: m.dragosavac@lboro.ac.uk

\section{Abstract}

A method for the production of near-monodispersed spherical silica particles with controllable porosity based on the formation of uniform emulsion droplets using membrane emulsification is described. A hydrophobic metal membrane with a $15 \mu \mathrm{m}$ pore size and $200 \mu \mathrm{m}$ pore spacing was used to produce near-monodispersed droplets, with a mean size that could be controlled between 65 and $240 \mu \mathrm{m}$ containing acidified sodium silicate solution (with 4 and $6 \%$ wt. $\mathrm{SiO}_{2}$ ) in kerosene. After drying, and shrinking, the final silica particles had a mean size in the range between 30 and $70 \mu \mathrm{m}$. The coefficient of variation for both the droplets and particles did not exceed 35\%. The most uniform particles had a 
mean diameter of $40 \mu \mathrm{m}$ and coefficient of variation of $17 \%$. By altering the $\mathrm{pH}$ of the sodium silicate solution and aging the gel particles in water, or acetone, the internal structure of the silica particles was successfully modified and both micro- and mesoporous near-monodispersed spherical particles were produced with an average internal pore size between 1 and $6 \mathrm{~nm}$ and an average surface area between 360 and $750 \mathrm{~m}^{2} \mathrm{~g}^{-1}$. A material balance and particle size analysis provided identical values for the internal voidage of the particles, when compared to the voidage as determined by BET analysis.

Keywords: Dispersion Cell, water in oil emulsion, sodium silicate, uniform particles

\section{Introduction}

In the last few decades there has been increasing interest in the production of porous inorganic materials with high surface area and internal porosity. Silica is an inorganic material that does not swell in solvents, it has very good mechanical and thermal stability as well as good dispersion characteristics in various solvents. Colloidal silica with a mean particle size ranging from about 5 to $100 \mathrm{~nm}$ has a wide range of applications as a thickener, adsorbent, molecular sieve, abrasive, additive, catalyst support, film coating or glass precursor $^{1}$. In addition to colloidal silica, there is significant commercial interest in porous spherical silica particles for use in analytical and preparative columns, requiring particle diameters greater than $1 \mu \mathrm{m}$. Such particles, if additionally functionalised, can have potential applications as ion exchangers ${ }^{2}$, biochemical sensors ${ }^{3}$, packing materials in chromatography columns ${ }^{4}$, drug delivery systems ${ }^{5}$, and catalysts ${ }^{6}$. Particle size and pore structure of silica particles directly influences mass transfer rate to, and from, the silica particle and its control is important in processes such as ion exchange, catalysis, chromatography, and drug delivery. Silica particles for larger-scale use, as scavengers in pharmaceutical processing or process-scale column applications, including ion exchange and adsorption, require a much larger particle size: up to $100 \mu \mathrm{m}$ in diameter. In these 
applications a uniform spherical particle is preferred to angular crushed solids, to minimise pressure drop and provide reproducible behaviour.

Silica particles can be produced from organic silicon compounds, e.g. siliciumalkoxide, such as tetraethyl or tetramethyl orthosilicate (TEOS and TMOS) or inorganic materials (sodium silicate). Sodium silicate is the cheapest source of silicon for silica particles. To produce silica gel, sodium silicate solution can be diluted with an acid to form silicic acid $\left(\mathrm{Si}(\mathrm{OH})_{4}\right)$ which then through condensation polymerization loses water and creates - $\mathrm{Si}-\mathrm{O}-\mathrm{Si}$ - bonds. Upon drying the formed hydrogel shrinks to a xerogel. A surfactant can be dissolved in the silica source to additionally tailor the internal gel structure (surfactant templating method) ${ }^{7}$. The characteristics of a produced dried gel are determined by the physical and chemical conditions at each step of the process of preparation.

To form spherical silica particles, acidified sodium silicate solution can be dispersed into an immiscible organic phase liquid, water in oil $(\mathrm{W} / \mathrm{O})$ emulsion route ${ }^{8}$, or spray dried ${ }^{1}$. In the $\mathrm{W} / \mathrm{O}$ emulsion route, the droplets of sodium silicate solution are dispersed in an appropriate immiscible organic solvent either by bulk emulsification, or by drop-by-drop emulsification. The dispersed droplets actually represent microreactors in which condensation polymerization occurs. Anderson et al. ${ }^{9}$ used the $\mathrm{W} / \mathrm{O}$ emulsion route in combination with solvent evaporation to produce spherical silica particles. They applied stirring to produce the emulsion and reported particles of up to $40 \mu \mathrm{m}$ with a broad size distribution. Size and uniformity of the silica particles produced was largely dependent upon the size and uniformity of the silica precursor droplets and, therefore, the controllable drop-by-drop emulsion formation is preferred. Several single channel microfluidic technologies have been reported for the production of spherical silica particles: Chen et al. ${ }^{10}$ injected a dispersed aqueous phase (a mixture of silica sol, acrylamide and initiator) through a needle into a cross-flowing oil phase to produce porous silica particles by calcination of polyacrylamide-silica composite particles. Charrol et al. ${ }^{11}$ injected a silica precursor (acidified TEOS solution with triblock copolymer) using a flow focusing oil, while Chokkalingam et al. ${ }^{12}$ fabricated silica particles by self-synchronized pairwise production of droplets of different solutions (acidified TEOS solution and ammonia solution) using a microfluidic cross junction 
followed by in situ droplet merging. The produced particles were above $10 \mu \mathrm{m}$ and very uniform, with a coefficient of variation of less than $5 \%$, but reported productivity was below $0.02 \mathrm{ml} \mathrm{min}{ }^{-1}$. Microchannel emulsification ${ }^{13}$, where the dispersed phase is pressed through uniformly sized microchannel arrays fabricated on a silicon microchip into the continuous phase, can be used for fabrication of uniform droplets. The disadvantage of this process is quite low productivity which does not exceed $0.025 \mathrm{ml} \mathrm{min}^{-1}$ for a grooved-type plate. Productivity of the process is crucial in industrial applications and, therefore, microfluidic devices or microchannel emulsification are not promising due to their limited ability to scale for production purposes.

In membrane emulsification, the dispersed water phase is pressed though a hydrophobic membrane and the droplets are detached into the continuous oil phase. Emulsions are prepared with a low shear stress $^{14}$ or even without any shear ${ }^{15}$, at a low energy input per unit volume compared with conventional emulsification methods, which allows for better control of droplet size and uniformity ${ }^{16}$. The shear on the membrane surface can be induced by stirring ${ }^{15}$ or cross-flow ${ }^{16}$ of the continuous phase, rotation of the membrane ${ }^{17}$, or oscillation of the membrane ${ }^{18}$. The droplet size is mainly controlled by the membrane pore size, flux of the dispersed phase through the membrane, shear applied on the membrane surface, chemistry of the formulation and the membrane, and finding the optimal combination is vital for the production of uniform droplets. It is well established that the droplet size is directly proportional to the membrane pore radius and the proportionality constant equals $3-20^{19,} 20$. Productivity for membrane emulsification can go up to a few thousand $\mathrm{ml} \mathrm{min}^{-1}{ }^{18}$, therefore, from the point of industrial application the process is quite promising. Production of spherical silica particles using the $\mathrm{W} / \mathrm{O}$ emulsion route and membrane emulsification has been reported by several authors (Table 1) but membranes with tortuous pores were used. These membranes can be easily fouled by the precursor solution and the reported mean particle size did not exceed $5 \mu \mathrm{m}$. These sizes may be appropriate for analytical column use, but for larger scale 'process' column applications particle diameters between 10 and $100 \mu \mathrm{m}$ are desirable. 
Table 1. Silica particles produced using the $\mathrm{W} / \mathrm{O}$ emulsion route and membrane emulsification (DP: dispersed phase, CP: continuous phase).

\begin{tabular}{|c|c|c|c|c|}
\hline Membrane & $\begin{array}{l}\text { Particle } \\
\text { size }\end{array}$ & Emulsion formulation & $\begin{array}{l}\text { Post-emulsification } \\
\text { treatment }\end{array}$ & Ref. \\
\hline $\begin{array}{l}\text { Anodic porous } \\
\text { alumina } 0.125 \mu \mathrm{m}\end{array}$ & $0.05-0.2 \mu \mathrm{m}$ & $\begin{array}{l}\text { DP: } 1 \mathrm{M} \mathrm{Na}_{2} \mathrm{SiO}_{3} \text { in water } \\
\mathrm{CP}: 2 \mathrm{wt} \% \text { Tween } 85 \text { in mixture } \\
\text { of hexane and cyclohexane (1:4 } \\
\text { by volume) }\end{array}$ & $\begin{array}{l}\text { Emulsion mixed with } 4 \\
\mathrm{wt} \% \text { aqueous } \\
\left(\mathrm{NH}_{4}\right)_{2} \mathrm{CO}_{3} \text { solution }\end{array}$ & 21 \\
\hline $\begin{array}{c}\text { SPG } 1.5 \mu \mathrm{m} \\
\text { Silica monolithic } \\
2 \mu \mathrm{m}\end{array}$ & Up to $3 \mu \mathrm{m}$ & $\begin{array}{l}\text { DP: Colloidal silica }\left(\mathrm{SiO}_{2} \text { : }\right. \\
20 \% \text {; mean diameter of silica } \\
\text { beads: } 10-20 \mathrm{~nm}) \\
\mathrm{CP}: 1 \mathrm{wt} \% \text { Span } 20 \text { in kerosene }\end{array}$ & $\begin{array}{l}\text { Emulsion mixed with } \\
0.5 \mathrm{M} \text { aqueous } \mathrm{NH}_{4} \mathrm{Cl} \\
\text { solution }\end{array}$ & 22 \\
\hline SPG $0.98-2.7 \mu \mathrm{m}$ & Up to $1 \mu \mathrm{m}$ & $\begin{array}{l}\mathrm{DP}: \mathrm{Na}_{2} \mathrm{SiO}_{3}+\text { sulfonic acid in } \\
\text { water, final } \mathrm{pH} 2 \\
\begin{array}{l}\mathrm{CP}: 2-10 \\
\text { toluene }\end{array}\end{array}$ & - & 23 \\
\hline $\begin{array}{c}\text { Sol-gel derived } \\
\text { macroporous glass } \\
\text { SPG }\end{array}$ & $3 \mu \mathrm{m}$ & $\begin{array}{l}\text { DP: Colloidal silica } \\
\text { CP: Span } 20 \text { in toluene }\end{array}$ & $\begin{array}{l}\text { Dripping } 2 \mathrm{M} \quad \mathrm{NH}_{4} \mathrm{OH} \\
\text { into emulsion }\end{array}$ & 24 \\
\hline
\end{tabular}

Cross-flow membrane emulsification, where the shear is induced by the recycled flow of the continuous phase, is not convenient for the production of droplets larger than $20 \mu \mathrm{m}$, due to droplet break up in the pump. This paper reports a novel W/O emulsion route combined with a metal microsieve-type membrane emulsification to prepare near-monodispersed porous spherical silica particles with a controllable size between 30 and $70 \mu \mathrm{m}$. The silica precursor solution was the inexpensive and environmentally friendly sodium silicate solution acidified with sulfuric acid. The precursor droplets were dispersed in kerosene using a Dispersion Cell with hydrophobic nickel membranes composed of straight non-interconnected pores. The influence of the shear stress on the initial droplet size of acidified sodium silicate solution and a relationship between the initial droplet size and the final silica particle size is reported. To predict the initial droplet size of the acidified sodium silicate solution, after injection, a model introduced in previous work $^{15}$ was used. The droplet diameter $x$ is calculated from a force balance of the capillary force (a function of interfacial tension and pore size) and the drag force (a 
function of a shear stress and the droplet size) acting on a strongly deformed droplet at a single membrane pore:

$$
x=\frac{\sqrt{18 \tau_{a v}{ }^{2} r_{p}^{2}+2 \sqrt{81 \tau_{a v}{ }^{4} r_{p}{ }^{4}+4 r_{p}{ }^{2} \tau_{a v}{ }^{2} \gamma^{2}}}}{3 \tau_{a v}}
$$

where $r_{p}$ is the pore radius, $\tau_{a v}$ is the average shear stress, $\gamma$ is the interfacial tension and $x$ is the formed droplet diameter. The average $\operatorname{shear}^{25}$ over the whole membrane area is given by:

$$
\tau_{a v}=\frac{\int_{0}^{r_{\text {trans }}} 0.825 \mu \omega r \frac{1}{\delta}(2 \pi r) d r+\int_{r_{\text {trans }}}^{D_{m} / 2} 0.825 \mu \omega r_{\text {trans }}\left(\frac{r_{\text {trans }}}{r}\right)^{0.6} \frac{1}{\delta}(2 \pi r) d r}{\pi D_{m}^{2} / 4}
$$

where $D_{\mathrm{m}}$ is the effective diameter of the membrane, i.e. the diameter exposed to the continuous phase, $r_{\text {trans }}$ is the transitional radius, $r$ is the distance from the axis of rotation, $\rho$ is the continuous phase density, $\omega$ is the angular velocity, $\mu$ is the continuous phase coefficient of dynamic viscosity and $\delta$ is the boundary layer thickness

$$
\delta=\sqrt{\mu / \omega \rho}
$$

Besides the size of the silica particles, the internal structure was also regulated by changing the initial $\mathrm{pH}$ of the acidified silica source and applying aging of the hydrogel in solvents with different surface tensions.

\section{Experimental section}

\section{Preparation of silica particles.}

The silica precursor was prepared by diluting sodium silicate solution $\left(28\right.$ wt $\% \mathrm{SiO}_{2}, 14 \mathrm{wt} \% \mathrm{Na}_{2} \mathrm{O}$, Fisher Scientific UK) down to 10 or $15 \mathrm{wt} \% \mathrm{SiO}_{2}$ using Milli-Q water $(18.2 \mathrm{M} \Omega \mathrm{cm})$. Once diluted the solution was stirred for $30 \mathrm{~min}$. Due to the gelling, the sol had to be prepared prior to the experiment by adding the diluted sodium silicate, with 10 or $15 \mathrm{wt} \% \mathrm{SiO}_{2}$, dropwise to $1 \mathrm{M} \mathrm{H}_{2} \mathrm{SO}_{4}($ Fisher Scientific 
UK). Approximately $17 \mathrm{ml}$ of diluted sodium silicate was added to $25 \mathrm{ml}$ of $\mathrm{H}_{2} \mathrm{SO}_{4}$ under vigorous stirring until the desired $\mathrm{pH}$ was achieved.

The gelling time is a function of $\mathrm{pH}$, therefore, the right $\mathrm{pH}$ of the silicate solution after dilution with acid had to be selected. The condensation polymerization rate has a minimum at $\mathrm{pH} 2$, at the isoelectric point $^{1}$, and increases with increased $\mathrm{pH}$. If the polymerization is too slow, the rate of particle growth is also slow and the particles forming the gel will be small resulting in a more compact and microprous gel. To measure the gelling time of the solutions, $4 \mathrm{ml}$ of the solutions with the $\mathrm{pH}$ 's of 1.5, 2.5, 3.5 and 4.5 were placed into plastic tubes and closed. The longest gelling time (longer than $24 \mathrm{~h}$ ) had a solution with $\mathrm{pH}$ of 1.5 while the solution with $\mathrm{pH} 4.5$ gelled in $30 \mathrm{~min}$. If the gelling time is long, droplet coalescence or breakage is more likely during the mixing stage. A pH of 3.5 was selected for most of the experiments, since it allowed for the injection of up to $50 \mathrm{~cm}^{3}$ of dispersed phase using the lowest selected flow rate $\left(1 \mathrm{ml} \mathrm{min}{ }^{-1}\right)$ without fear of membrane blocking by the gelling solution. At this $\mathrm{pH}$ significant gelling did not take place until after 1 hour. Both sodium silicate and sulfuric acid were used without any purification.

Emulsification using a stationary membrane was performed using a Micropore Technologies Ltd. Dispersion Cell. This device uses a 24 V DC motor to drive a paddle-blade stirrer, which provides the shear at the membrane surface (Fig. 1a). Stirrer speeds between 180 and $1400 \mathrm{rpm}$ were used. For the production of W/O emulsions hydrophobic membranes were used (Fig. 1a), including one with a smaller active ring area of pores and another where all of the pores were used ${ }^{26}$. All membranes had a $15 \mu \mathrm{m}$ pore size, and $200 \mu \mathrm{m}$ spacing between the pores, and were kindly provided by Micropore Technologies Ltd. The active surface area of the whole and the ringed membrane was 8.0 and $2.8 \mathrm{~cm}^{2}$, respectively. The continuous phase was prepared by dissolving $5 \mathrm{wt} \%$ Span 80 in low odour kerosene (both supplied by Sigma Aldrich, UK). Span 80 is an emulsifier to stabilise the aqueous sol droplets formed in the kerosene. The inlet hose was filled with the continuous phase prior to each experiment to ensure that air was not entrapped within the oil phase. The cell was filled with $100 \mathrm{~cm}^{3}$ of continuous phase and in most experiments $10 \mathrm{~cm}^{3}$ of dispersed phase (silica precursor solution) was injected 
through the membrane pores using a Harvard Apparatus model 11 Plus syringe pump. After production, the silica droplets were transferred to a Teflon beaker and kerosene was added to dilute the volume concentration in order to minimise droplet coalescence. Before the transition of the droplets into gel was complete the emulsion had to be subjected to continuous stirring to prevent settling and coalescence of the droplets. The stirring rate during gelling was found to be of great importance. If too high stirring was applied particles suffered attrition during solidification, therefore, $170 \mathrm{rpm}$ was determined to be the most appropriate rate for the experiments: sufficient to keep the droplets suspended and separated, without causing shear deformation, or crushing, of the forming particles. When droplets of dispersed phase were initially injected into the kerosene solution it became milky white, and stirring was maintained until the kerosene solution became transparent again, and the hydrogel was formed. All the diluted solutions injected into the continuous phase were clear and transparent without any visible particulates, hence the milky colouration was believed to be due to water transport within the Span 80 stabilised continuous phase.

\section{Washing of silica particles.}

After the gelling, it was noticed that besides the spherical silica particles, very small amounts of needle shaped silica particles could also be created. So, to separate the spherical particles, a microfiltration cell was used (Fig. 1b). The microfiltration cell is identical to the Dispersion Cell apart from the use of a slotted membrane attached at the bottom of the cell (Fig. 1b). The slotted membrane was kindly provided by Micropore Technologies Ltd. The slots were $4 \mu \mathrm{m}$ wide and $250 \mu \mathrm{m}$ long 
(a)

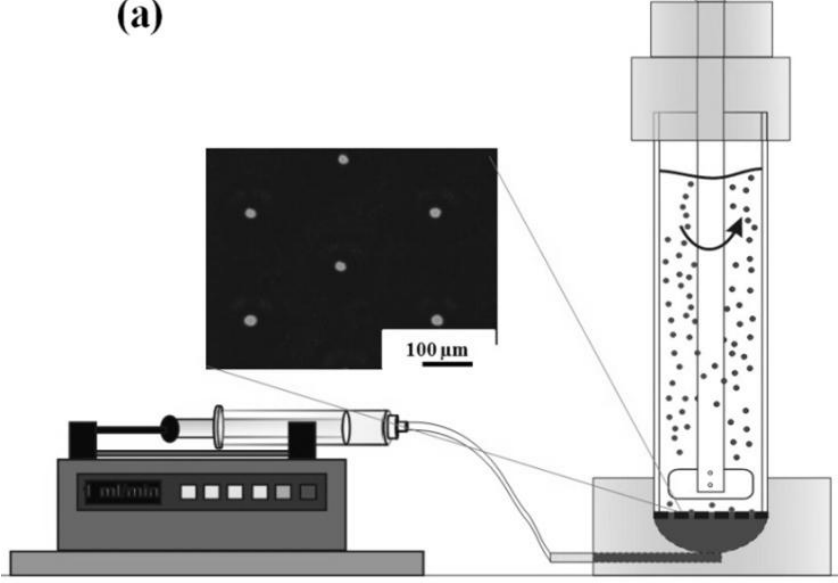

(b)

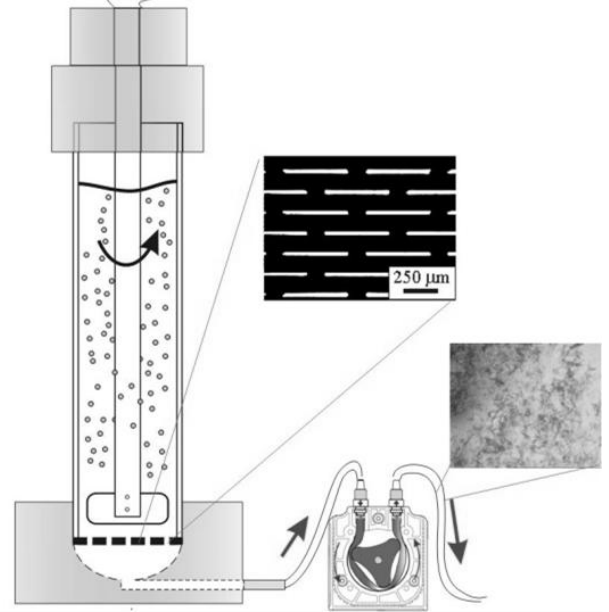

Figure 1 Schematic illustration of: (a) Dispersion Cell containing a paddle stirrer above a disk membrane with circular $15 \mu \mathrm{m}$ pores used for membrane emulsification and (b) microfiltration system together with slotted pore membrane and photomicrograph of the filtrate.

ensuring that even the smallest silica particles were maintained above the membrane. The advantage of the slotted membrane over a regular membrane is that the pores cannot be clogged with the small particles, as is the case with conventional membranes ${ }^{27,28,29}$. The silica particles were retained by the membrane while the needle-like material passed through the pores. All of the filtrate collected during the filtration was dried to identify the amount of silica lost as needles. No spherical particles were observed in the filtrate and the amount of needle-like silica in the filtrate was less than $2 \%$ of the total particle mass being filtered. In order to remove Span 80 and kerosene from the particles acetone washing was used. Once the kerosene was filtered off, the cell was partially filled with acetone and the spherical silica particles were washed with acetone. For filtrate removal a peristaltic pump (WatsonMarlow-Bredel Pump 101U/R, UK) was used which operated at $0.1 \mathrm{ml} \mathrm{min}{ }^{-1}$. Each batch of spherical silica particles was continuously washed with at least $250 \mathrm{~cm}^{3}$ of fresh acetone followed by water washing. After drying at room temperature, when the particles no longer aggregated together, calcination at $550^{\circ} \mathrm{C}$ with a ramp step of $20^{\circ} \mathrm{C} \mathrm{min}^{-1}$ for 6 hours was used. Calcination completed the removal of the surfactant, and kerosene, from the surface and the drying and shrinkage of the particles.

\section{Droplets / Particles characterization.}




\section{Optical Microscopy.}

The sizes of freshly prepared droplets of dispersed phase in kerosene, hydrogel as well as xerogel (fully dried hydrogel) particles were determined using a Leitz Ergolux optical microscope with attached Pulnix TM-6CN monochrome camera. The droplets tended to burst when placed on a microscopic slide due to surface tension effects, so photographs of the droplets had to be taken very quickly. For each experiment, numerous photos were taken and at least 700 droplets, or particles, were measured for representative measurements of size. As an indication of the droplet size distribution, the coefficient of variation was determined using the Java-based image processing package ImageJ. An example of a Scanning Electron Microscopy (SEM) image of the particles, and image converted for processing in ImageJ, is given in Figure 2.

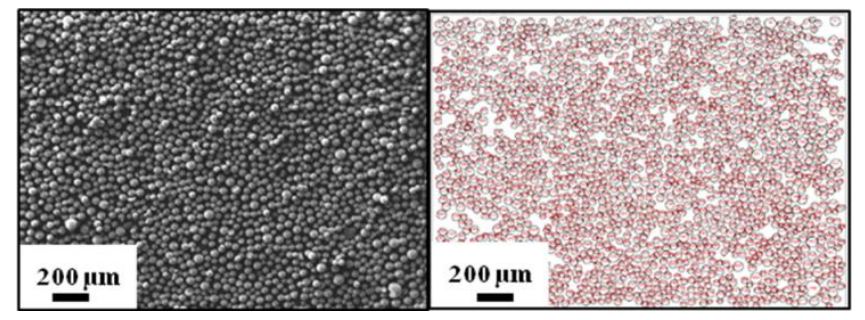

Figure 2 SEM image and outlined particles for ImageJ analysis of silica particles with an average particle size of $30 \mu \mathrm{m}$.

\section{Surface analysis.}

Studies of dried silica particles by SEM were performed using a Stereoscan 360 (Cambridge Instruments, UK). An Oxford Instruments INCA system attached to the SEM was used for energydispersive X-ray microanalysis (EDX) of the silica surface. More detailed photos of the silica surface were obtained using Leo 1530 VP Gemini (Carl Zeiss) high resolution field emission gun scanning electron microscope (FEG SEM). To prevent the accumulation of static electric charge on the particles during electron irradiation prior to the SEM and FEG SEM analysis silica particles were coated for several minutes with a mixture of gold and palladium ( $80 \%$ gold and $20 \%$ palladium). The thickness of the sputter coating was $0.85 \mathrm{~nm}$ per second at $2 \mathrm{kV}$ and $25 \mathrm{~mA}$ of plasma current. 
The internal morphology of the dried silica particles (xerogel) was investigated using an ASAP 2020 Micromeritics (Accelerated Surface Area and Porosimetry system). Prior to the analysis, samples were subjected to dehydratation in vacuum at $100^{\circ} \mathrm{C}$ for 16 hours. The dehydrated silica particles $(200 \mathrm{mg})$ were loaded and degassed under different temperatures for several hours under vacuum, followed by analysis at $-197^{\circ} \mathrm{C}$ with $\mathrm{N}_{2}$ as the adsorbate gas. The pore size distribution was calculated by the Barrett-Joyner-Halenda $(\mathrm{BJH})$ method $^{30}$. The nitrogen isotherm was fitted with the Brunauer-EmmettTeller (BET) model $^{31}$ to evaluate the surface area, and the cumulative pore volume was calculated from the extrapolation of the isotherm to a relative pressure of 0.99 .

\section{Results and discussion}

The aim of this work was to produce uniform spherical silica particles, within the size range of 30 to $70 \mu \mathrm{m}$, with controllable internal porosity, starting from sodium silicate and sulfuric acid, using stirred cell membrane emulsification. No literature data on the production of $\mathrm{W} / \mathrm{O}$ emulsions (acidified sodium silicate/kerosene) using the Dispersion Cell and hydrophobic membranes (Fig. 1a) was available, therefore, the reproducibility of the experiments had to be tested. For the tests, the paddle rotation was set to $875 \mathrm{rpm}$ while the flow rate of the dispersed phase was set to $5 \mathrm{ml} \mathrm{min}^{-1}$ (corresponding to a flux of $\left.350 \mathrm{~L} \mathrm{~m}^{-2} \mathrm{~h}^{-1}\right)$. Four experiments were conducted and the mean droplet sizes $(d)$ as well as the coefficient of variations $(\mathrm{CV})$ are presented in Fig. 3. In the experiments, marked as 1 and 2, the volume

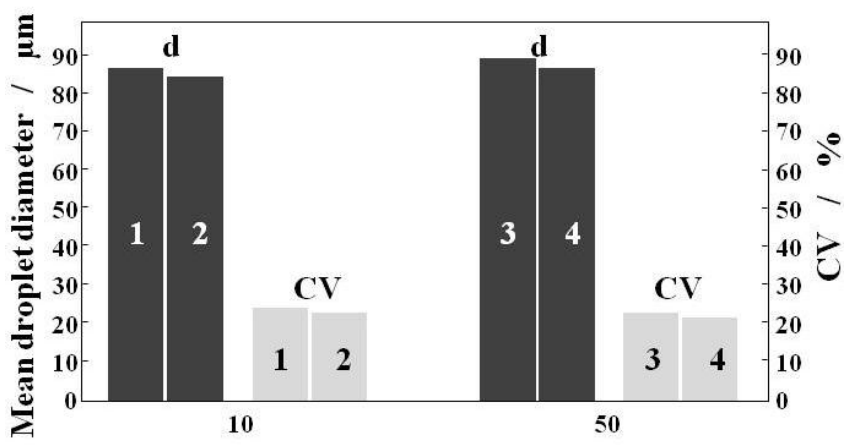

Injected volume of dispersed phase / $\mathrm{cm}^{3}$ 
Figure 3 Reproducibility of the repeated experiments: $10 \mathrm{~cm}^{3}$ of dispersed phase was injected into the continuous phase in the exp. 1 and 2 while $50 \mathrm{~cm}^{3}$ was injected in the exp. 3 and $4 . \omega=875 \mathrm{rpm}$ and $J_{d}=350 \mathrm{~L} \mathrm{~m}^{-2} \mathrm{~h}^{-1} . d$ represents mean droplet size and $C V$ represents coefficient of variation.

of dispersed phase injected through the membrane was $10 \mathrm{~cm}^{3}$ while in experiments 3 and 4 it was 50 $\mathrm{cm}^{3}$. After each experiment the membrane was sonicated for $30 \mathrm{~min}$ in a warm detergent solution, washed with clean water and dried with compressed air. It was soaked for one hour in kerosene prior to an experiment in order to increase the hydrophobicity of the membrane. As can be seen from the Fig. 3, the mean droplet size $(d)$ as well as the coefficient of variation $(C V)$ remained almost unchanged no matter what volume of dispersed phase was injected into the continuous phase, which provided evidence that the experiments were reproducible and gave a mean droplet size $(d)$ of just below $90 \mu \mathrm{m}$ with a coefficient of variation $(\mathrm{CV})$ in the range between 22.5 and $23.5 \%$ for the described combination of rotation speed and flow rate. Furthermore, these experiments demonstrated that neither the dispersed phase, nor surfactant (Span 80), adsorbed onto the membrane surface within the time allowed for the experiments: such an effect would have caused membrane 'wetting' with a consequential increase in droplet size (and probably lowering of $\mathrm{CV}$ ).

When using the Dispersion Cell for the production of emulsions, the two main parameters affecting the droplet size are paddle rotation speed and flow rate of the dispersed phase ${ }^{15,25,26}$. Fig. 4 illustrates both influences: shear stress as well as flux of the dispersed phase, on droplet size. The error bars in Fig. 4 represent one standard deviation from the mean value, and the theoretical prediction based on Eqs. (1) and (2) is shown by the curve. As can be seen from the figure, the rotation speed represents an effective way to control the droplet size. An increase of the rotation speed increases the shear stress on the membrane surface and the droplet formation time shortens, therefore, the droplets produced at higher rotation speed have a smaller diameter. Using the flow rate of $5 \mathrm{ml} \mathrm{min}^{-1}$ and the rotation speed from 200 to $1400 \mathrm{rpm}$, mean droplet sizes in the range between 240 and $65 \mu \mathrm{m}$ were produced. 
Eqs. (1) and (2) gave good predictions of the droplet sizes produced at a very low flow rate $\left(1 \mathrm{ml} \mathrm{h}^{-1}\right.$ equivalent to approximately $1 \mathrm{~L} \mathrm{~m}^{-2} \mathrm{~h}^{-1}$ ). Several variations of the force balance model have been developed for predicting the droplet size in the Dispersion Cell ${ }^{15,25,32}$. Kosvintsev et al. ${ }^{15}$ used maximal shear stress in the force balance model and Dragosavac et al. ${ }^{25}$ used average shear stress. Egidi et al. ${ }^{32}$ added the "push off" force to the force balance model to predict the droplet size at high flow rates when the space between the pores is small. The shear stress on the membrane surface does depend on the distance from the axis of rotation and reaches its greatest value at the transitional radius ${ }^{15}$. Since the shear stress on the membrane surface is not constant the average shear stress is more representative in the case of the whole membrane which was used here. Since the model does not take into consideration the flow rate of the discontinuous phase, it is expected that the model will predict the droplets produced using a very low flow rate, as shown in Fig. 4. In the case of the very low flow rate, the volume of

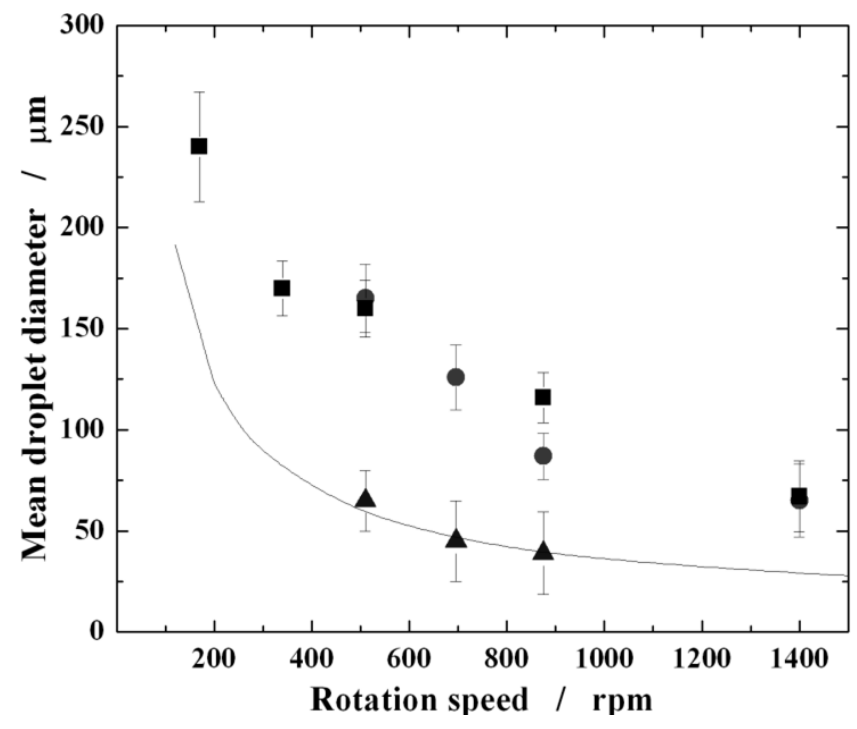

Figure 4 Experimental droplet diameters of produced water-in-oil emulsions as a function of rotation speed. The line represents the model (Eqs. (1) and (2)) for predicting the droplet size. (घ) $6 \mathrm{wt}$ $\% \mathrm{SiO}_{2}\left(\right.$ Sodium silicate $\left.+1 \mathrm{M} \mathrm{H}_{2} \mathrm{SO}_{4}\right)$ injected at $350 \mathrm{~L} \mathrm{~m}^{-2} \mathrm{~h}^{-1}$. (•) $4 \mathrm{wt} \% \mathrm{SiO}_{2}($ Sodium silicate +1 $\mathrm{M} \mathrm{H}_{2} \mathrm{SO}_{4}$ ) injected at $350 \mathrm{~L} \mathrm{~m}^{-2} \mathrm{~h}^{-1}$. ( $\left.\boldsymbol{\Delta}\right) 6 \mathrm{wt} \% \mathrm{SiO}_{2}$ (Sodium silicate + distilled water) injected at $1 \mathrm{~L}$ $\mathrm{m}^{-2} \mathrm{~h}^{-1}$ 
sulfuric acid used to initialize the gelling was replaced with dionised water, in order to avoid particle gelling during injection through the membrane. Such replacement was necessary, since the experiment had to last for several hours in order to produce enough droplets for analysis, and if the solution was acidified the sodium silicate would gel within the tubing and membrane. These experiments were performed solely to assess the validity of the force balance model with this system. The droplets produced using the higher flow rate followed the same trend as the ones produced at the lower transmembrane flux: an increased rotational speed decreased the droplet size, but the droplet sizes produced at the higher transmembrane flux caused deviation from the model. Two explanations of this phenomenon are possible. First, the detachment of the droplet is not instantaneous but requires a finite time $t_{\text {neck }}$, the necking time, during which an additional amount of dispersed phase flows into the droplet. Therefore, the resultant droplet volume, $V$, is larger than the one estimated by the force balance model and can be expressed as ${ }^{34}$ :

$V=V_{\text {crit }}+\left(t_{\text {neck }} / k\right)\left(Q_{d} / N\right)$

where $V_{\text {crit }}$ is the droplet volume predicted by the model, $k$ is the fraction of active pores, $Q_{d}$ is the total dispersed phase flow rate and $N$ is the total number of pores in the membrane. For the data in Fig. 4 obtained at $350 \mathrm{~L} \mathrm{~m}^{-2} \mathrm{~h}^{-1}$, the above equation gives values of $t_{\text {neck }} / k$ in the range from $0.08 \mathrm{~s}$ at $1400 \mathrm{rpm}$ to $3.4 \mathrm{~s}$ at $200 \mathrm{rpm}$. The fraction of active pores $k$ usually ranges from 2 to $50 \%$, which means that $t_{\text {neck }}$ should vary from $0.002-0.08 \mathrm{~s}$ at $1400 \mathrm{rpm}$ to $0.07-1.7 \mathrm{~s}$ at $200 \mathrm{rpm}$. Another reason for the deviation between the model predictions and experimental data at $350 \mathrm{~L} \mathrm{~m}^{-2} \mathrm{~h}^{-1}$ is insufficient coverage of the droplet surface with Span 80 molecules during formation of the drops. The model calculations are made using the equilibrium interfacial tension which is lower than the actual interfacial tension during drop formation. Less coverage of the droplet surface by surfactant leads to greater interfacial tension force and the resultant droplet is larger.

It is clear that too low and too high rotation speed is not recommended for the production of uniform droplets, as shown by the longer error bars in Fig. 4. The decrease in uniformity probably originates from droplet breakup: at low rotation speeds large droplets are created which are more susceptible to 
breakage by the stirrer, and at high rotation speeds breakage is quite likely. Other dispersed phase injection rates were tested, but a dispersed phase flow rate of $5 \mathrm{ml} \mathrm{min}^{-1}$ gave the most uniform droplets regardless of paddle rotation speeds. No major difference in droplet uniformity and mean droplet diameter was observed for the droplets containing 4 and $6 \mathrm{wt} \% \mathrm{SiO}_{2}$. Both solutions have similar viscosity and density values, therefore, the final droplet size should be the same and Fig. 4 confirms this prediction. The higher content of silica was used in further experiments, since it is likely to give stronger silica particles. Concentrations higher than $6 \mathrm{wt} \% \mathrm{SiO}_{2}$ were not used, since it was observed that the solutions were not clear after the addition of sulfuric acid.

In some applications the restriction of active membrane area to a ring encompassing the transitional radius may help to improve the uniformity of the formed droplets ${ }^{26,36}$. The argument here is that the shear stress on the membrane surface due to the stirring is not uniform under the paddle, and the region where the shear reaches its maximum will provide the most consistent region of shear. A ringed membrane was tested for the production of the droplets, but no significant improvement in uniformity was observed in this case.

The produced droplets were transferred into a Teflon beaker, and stirred using a low rotation speed in order to allow gelling and formation of a hydrogel. Once gelled, the hydrogel particles were dried to form a xerogel. Fig. 5 illustrates the shrinkage of the dispersed phase droplets and their transformation; firstly into the hydrogel and then to the xerogel forms. During condensation polymerization, the droplets will shrink due to water loss as the hydrogel is formed. To remove kerosene and Span 80 a suspension of gel particles was transferred into a microfiltration cell and the kerosene was filtered, followed by washing in acetone and then water. The washed particles were left to completely dry for several days at room temperature. During this drying stage liquid present in the pores was removed, the structure was compressed and the porosity was reduced, at least to some degree, by the surface tension forces as the liquid was removed, leaving spherical silica particles (xerogel). Drying at room temperature was followed by calcination, but further shrinkage of the dried silica particles was not observed. Shrinkage 
of the droplets during the drying process can be seen in Fig. 5. The markers in Fig. 5 represent the final

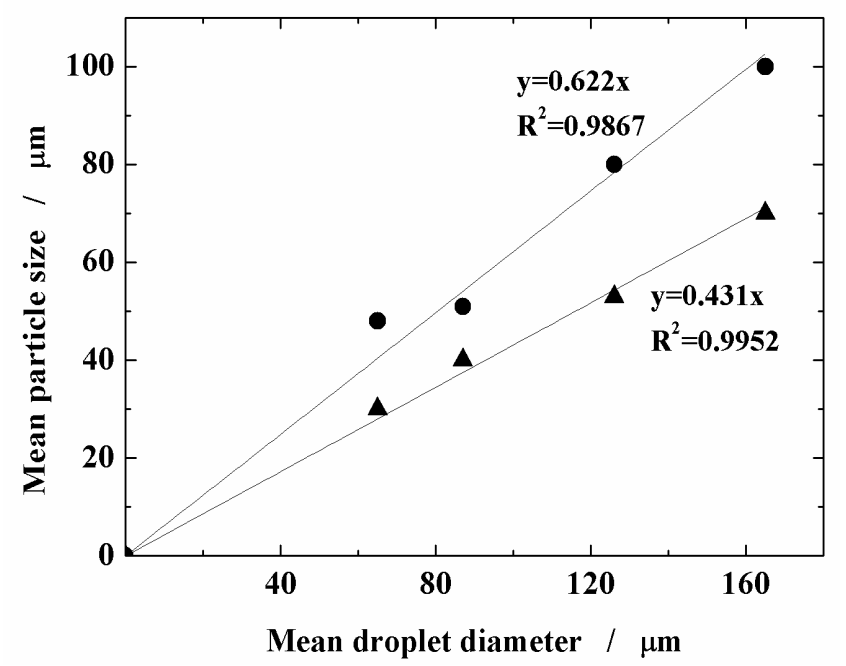

Figure 5 Relationship between the particle diameter in the resultant gels and the droplet diameter.

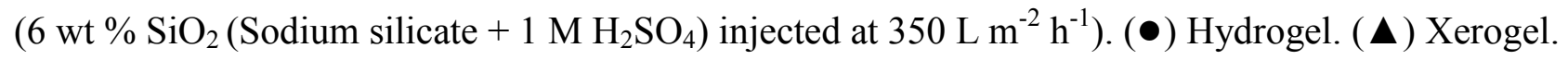

particle size of the gel (hydrogel and xerogel) as a function of the initial droplet size and the lines represent best fits to the experimental data. The final particle size was found to be an approximately linear function of the initial droplet size. The final silica particles (xerogel) were 2.3 times smaller than the initial droplet size. However, the particles were still significantly bigger than would be predicted by a mass balance of the silica used in their formation. For example, the $120 \mu \mathrm{m}$ droplets would give rise to xerogel particles of $37 \mu \mathrm{m}$ based solely on a material balance on the silica present. Clearly, the larger size, $52 \mu \mathrm{m}$, is due to a significant amount of internal porosity, or voidage. This is discussed further after the dried particle characterization results.

Fig. 6 compares the $C V$ for droplets, hydrogel and xerogel particles as a function of rotation speed. 


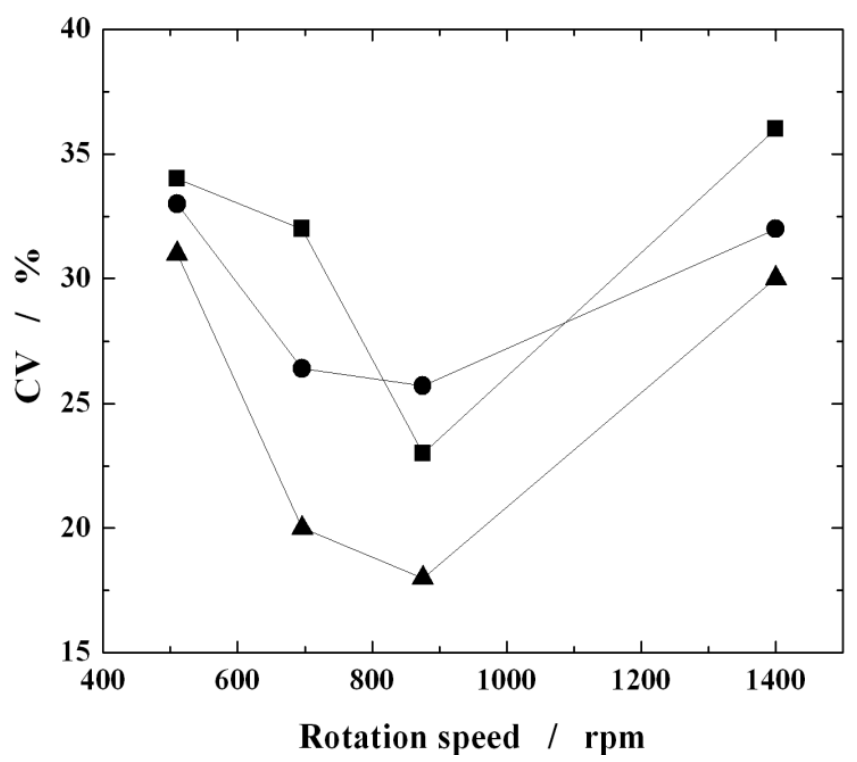

Figure 6 The coefficient of variation of silica particles in various stages during production as a function of rotation speed. ( $6 \mathrm{wt} \% \mathrm{SiO}_{2}$ (Sodium silicate $+1 \mathrm{M} \mathrm{H}_{2} \mathrm{SO}_{4}$ ) injected at $350 \mathrm{~L} \mathrm{~m}^{-2} \mathrm{~h}^{-1}$ ). (a) Droplets of acidified sodium silicate solution in kerosene immediately after production. (•) Hydrogel particles. ( $\mathbf{\Lambda})$ Xerogel particles.

It can be seen that the most uniform droplets were produced at an intermediate rotation speed of 875 $\mathrm{rpm}$. It is interesting to note that with the loss of water the particles became more uniform as illustrated in Fig. 6. Improvement in uniformity with the loss of water is also visible from Fig. 7 where the particles (7c and d) produced from the droplets (7a and b) are presented. Using a $15 \mu \mathrm{m}$ membrane spherical silica particles in the range between 30 and $70 \mu \mathrm{m}$ with a $C V<20 \%$ were produced.

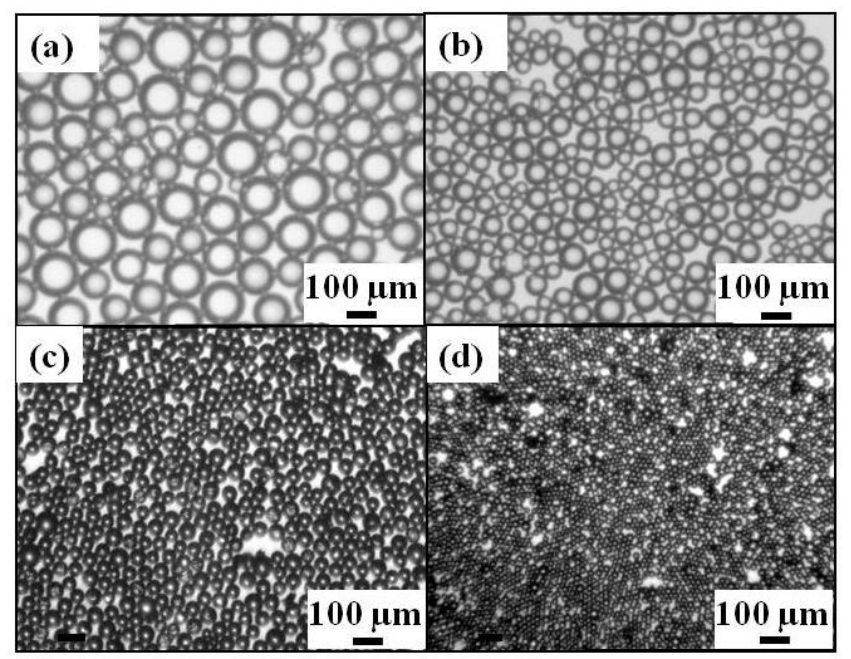


Figure 7 Optical micrographs of acidic sodium silicate droplets in kerosene produced at (a) 500 rpm and (b) $875 \mathrm{rpm}$. Optical micrographs of calcined silica particles produced from these droplets are shown in Figure (c) $30 \mu \mathrm{m}$ and (d) $50 \mu \mathrm{m}$, respectively.

The surface structure of the silica particles after calcination was imaged by SEM (operated at $2.6 \mathrm{kV}$ ) and FEG SEM (operated at $10 \mathrm{kV}$ ) and microphotographs are presented in Fig. 8. The silica particles are

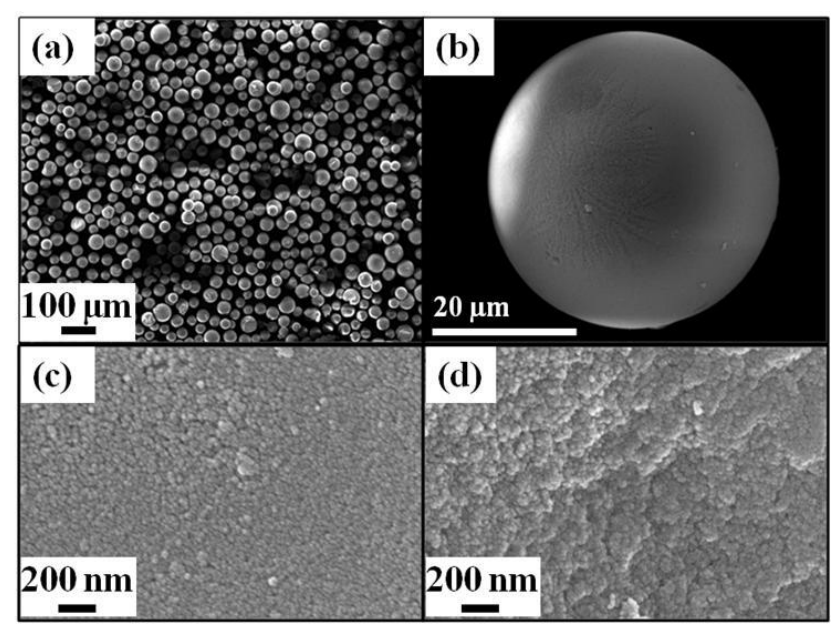

Figure 8 (a) Scanning electron micrograph (SEM) of the silica particles with an average size of 40 $\mu \mathrm{m}$. (b) SEM of a single silica sphere. (c) Field emission gun (FEG) SEM of a silica sphere external surface structure. (d) FEG SEM of a broken silica sphere.

almost perfectly round as can be seen from Figs. $8 \mathrm{a}$ and $8 \mathrm{~b}$, while the close-up of the particle surface shows a cloudy and corrugated external and internal surface morphology (Figs. 8c and 8d). On the surface the presence of pores is visible (Fig. 8(c)). To confirm the composition of the particles EDX elemental analysis was performed. Ten random silica particles were scanned and the averaged result of Energy Dispersive Spectrum is presented in Fig. 9. As can be seen, the particles consist of silicon and oxygen 


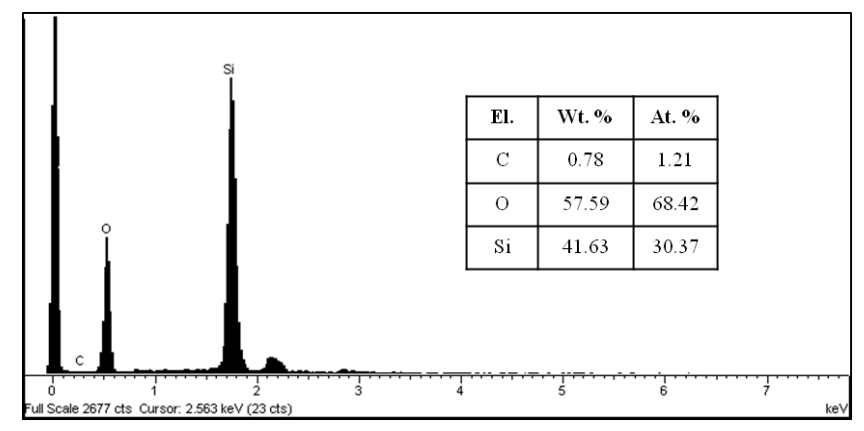

Figure 9 The Energy Dispersive Spectrum (EDS) of silica particles with average size of $40 \mu \mathrm{m}$.

with signals at 1.8 and $0.5 \mathrm{keV}$ respectively. At 0 and $2.2 \mathrm{keV}$ two signals can be seen: the first one comes from the background (i.e. the plate on which the particles were placed), while the other one comes from the gold and palladium which were used to coat the particles prior to SEM and FEG SEM analysis in order to reduce the charge interference.

Gel formation is based on the establishment of chemical bonds between neighboring particles and the particle size is a function of the $\mathrm{pH}$ of a silica precursor ${ }^{1}$. According to Iler ${ }^{1}$ after gelation, but before complete drying, the structure and chemistry may be altered by varying the $\mathrm{pH}$, salt concentration, temperature and/or pore fluid composition in a process called aging. Muñoz-Aguado et al. ${ }^{37}$ found that if gellation is performed under acid conditions $(\mathrm{pH} \leq 7)$, the final xerogel pore size depends mainly upon $\mathrm{pH}$. In order to modify the internal porosity, the $\mathrm{pH}$ of the dispersed phase was increased to 4.5 and aged in acetone. The particles were compared with the particles formed from the solution at $\mathrm{pH} 3.5$ and the hydrogel aged in water. The systematization of pores according to Dubinin ${ }^{38}$ : where micropores have diameter smaller than $3 \mathrm{~nm}$ and mesopores have diameters in the region between 3 and $200 \mathrm{~nm}$ is used in the discussion below. Fig. 10a shows a nitrogen adsorption-desorption isotherm of the silica synthesized under a $\mathrm{pH}$ of 3.5 , aged for 7 days in water and dried and calcined. The adsorption isotherm shows a steep rise in the low-pressure region at a normalized pressure of about $p / p_{0}<0.05$ and according to IUPAC (Sing et al. ${ }^{39}$ ) it is the type I isotherm which could be interpreted as an indication of the presence of micropores in the analyzed silica. The inset in Fig. 10a shows the pore size distribution calculated from the desorption isotherm according to the $\mathrm{BJH}$ method $^{30}$. The sample shows 
a wide pore size distribution in the micropore range with a distribution maximum at a pore radius of 1.5

$\mathrm{nm}$. Figure $10 \mathrm{~b}$ represents the silica sample produced from the acidified sodium silicate solution with a
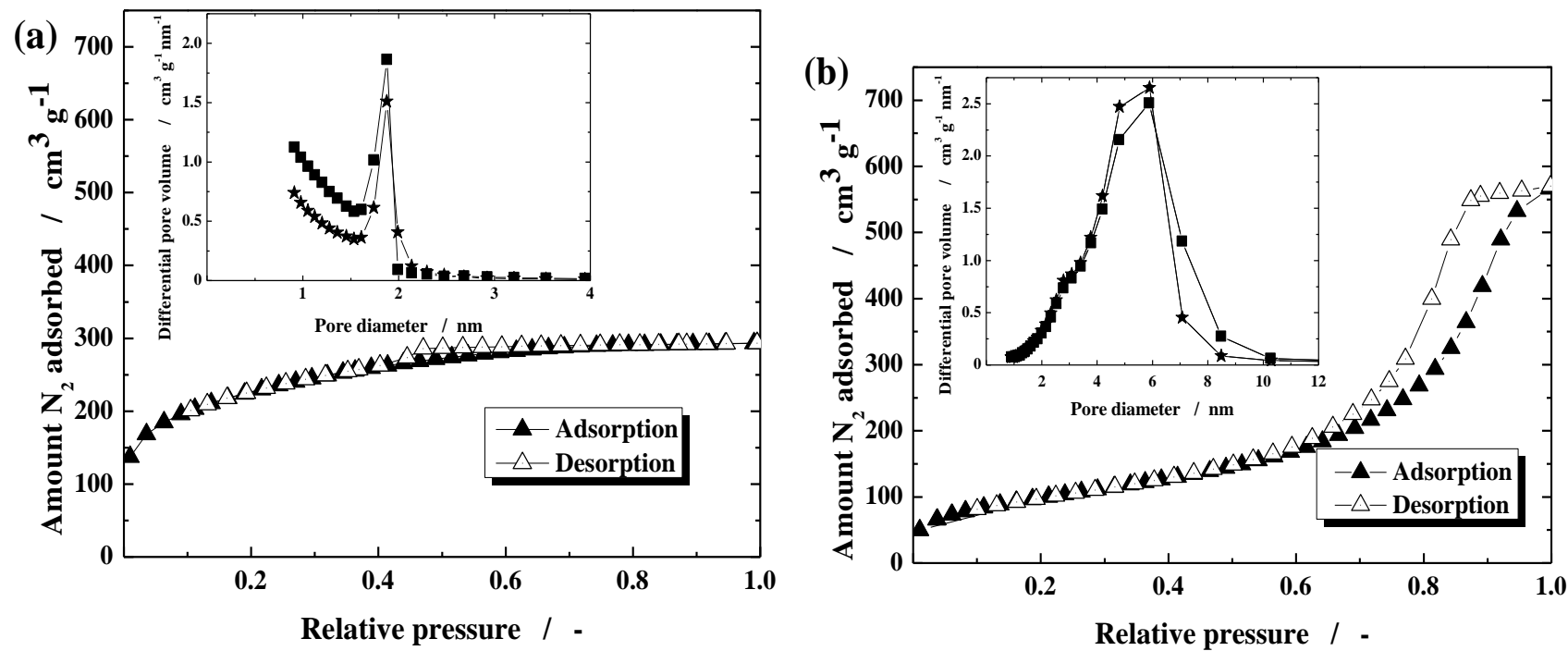

Figure 10a BET nitrogen adsorption-desorption isotherm of silica particles with an average size of $40 \mu \mathrm{m}$. Initial sodium silicate solution had $\mathrm{pH}=3.5$, and the produced hydrogel was aged 7 days in water followed by vacuum drying at $100^{\circ} \mathrm{C}$ and calcination for $4 \mathrm{~h}$ at $550^{\circ} \mathrm{C}$. Inset graph represents the pore size distribution calculated using the $\mathrm{BJH} \operatorname{method}^{30}$ according to the desorption isotherms for two different samples aged on the same way showing the reproducibility of the results.

Figure 10b BET nitrogen adsorption-desorption isotherm of silica particles with an average size of $40 \mu \mathrm{m}$. The initial sodium silicate solution had $\mathrm{pH}=4.5$, and the produced hydrogel was aged 7 days in acetone followed by vacuum drying at $100^{\circ} \mathrm{C}$ and calcination for $4 \mathrm{~h}$ at $550^{\circ} \mathrm{C}$. Inset graph represents pore size distribution calculated using $\mathrm{BJH}$ method ${ }^{30}$ according to the desorption isotherms for two different samples aged on the same way showing the reproducibility of the results.

$\mathrm{pH} 4.5$, aged for 7 days in acetone, before being dried and calcined. The adsorption isotherm has a characteristic hysteresis loop appearing between a relative pressure of $p / p_{0}=0.60$ and $p / p_{0}=1$ caused possibly due to capillary condensation corresponding to a type IV isotherm according to IUPAC (Sing et $\mathrm{al}^{39}$ ) indicating the presence of mesopores. The inset in the Fig. $10 \mathrm{~b}$ illustrates the pore size distribution (according to the $\mathrm{BJH}$ method $^{30}$ ) of the sample with a distribution maximum at a pore radius 
of $6 \mathrm{~nm}$. The results obtained are in accordance with the literature, since Muñoz-Aguado and Gregorkiewitz $^{40}$ reported that gelling reactions in the acid region is approximately second order with respect to silica concentration and a bimolecular condensation reaction is the rate determining step. The sol-gel process can be summarized ${ }^{41}$ as sodium silicate reacting with water to give silicic acid, which then polymerizes to form silica gel:

$$
\mathrm{Na}_{2} \mathrm{SiO}_{3}+\mathrm{H}_{2} \mathrm{O}+\mathrm{H}_{2} \mathrm{SO}_{4} \rightarrow \mathrm{Si}(\mathrm{OH})_{4}+\mathrm{Na}_{2} \mathrm{SO}_{4}
$$

The condensation polymerization forms small silica particle chains, which can then form a network of silica gel:

$$
n\left[\mathrm{Si}(\mathrm{OH})_{4}+(\mathrm{OH})_{4} \mathrm{Si}\right] \rightarrow n\left[\begin{array}{cc}
\mathrm{OH} & \mathrm{OH} \\
\mathrm{I} & \mathrm{I} \\
\mathrm{OH}-\mathrm{Si}-\mathrm{O}-\mathrm{Si}-\mathrm{OH} \\
\mathrm{I} & \mathrm{I} \\
\mathrm{OH} & \mathrm{OH}
\end{array}\right]+2 n \mathrm{H}_{2} \mathrm{O}
$$

When such mechanisms prevail, then according to Muñoz-Aguado and Gregorkiewitz ${ }^{40}$, a microporous texture is expected for the silica matrix. There have also been reports of the silica particles tending to form a linear chain, with low crosslink density, at low $\mathrm{pH}$ values ${ }^{41}$. This is consistent with the observed formation of a small amount of needle like crystals that were filtered out, as described above.

The specific surface area of the sample aged in water at $\mathrm{pH}=3.5$ was $760 \mathrm{~m}^{2} \mathrm{~g}^{-1}\left( \pm 21 \mathrm{~m}^{2} \mathrm{~g}^{-1}\right)$ with a cumulative pore volume $\left(V_{p}\right)$ of $0.45 \mathrm{~cm}^{3} \mathrm{~g}^{-1}\left( \pm 0.02 \mathrm{~cm}^{3} \mathrm{~g}^{-1}\right)$, determined using the BET multipoint method $^{31}$. In the case of the sample aged in acetone the specific surface area decreased to $360 \mathrm{~m}^{2} \mathrm{~g}^{-1}( \pm$ $\left.16 \mathrm{~m}^{2} \mathrm{~g}^{-1}\right)$ while the cumulative pore volume increased to $0.88 \mathrm{~cm}^{3} \mathrm{~g}^{-1}\left( \pm 0.03 \mathrm{~cm}^{3} \mathrm{~g}^{-1}\right)$. Note that the external specific surface area of the particles using the Mastersizer $2000 \mathrm{~S}$ (Malvern Instruments, UK) was determined to be just about $0.1 \mathrm{~m}^{2} \mathrm{~g}^{-1}$ which is negligible with respect to the internal surface area. The absolute density $\rho_{t}$ of the samples aged in water, or acetone, was measured using a Helium Pycnometer 9200 (Micromeritics, US) and was not found to differ significantly: $2070 \mathrm{~kg} \mathrm{~m}^{-3}( \pm 40 \mathrm{~kg}$ 
$\left.\mathrm{m}^{-3}\right)$. According to the cumulative pore volume $\left(V_{p}\right)$ and the absolute silica density $\left(\rho_{t}\right)$, the internal voidage $\left(\varepsilon_{s}=V_{p} /\left(V_{p}+1 / \rho_{t}\right)\right)$ of the samples aged in water and acetone is 47 and $63 \%$, respectively.

The analysis above compares favourably with a material balance based on the information contained in Fig. 5. The volume of solid silica contained in a droplet is

$$
m \frac{\pi}{6} x^{3} \frac{\rho}{\rho_{s}}
$$

where $m$ is the mass fraction of silica present in the liquid, $x$ is the droplet diameter, $\rho$ and $\rho_{s}$ are the acidified sodium silicate and solid silica densities, respectively. The internal voidage of the particle is

$$
\varepsilon_{s}=\frac{V_{\text {voids }}}{V_{\text {voids }}+V_{\text {solid }}}
$$

where $V_{\text {voids }}$ is the void volume and $V_{\text {solid }}$ is the solid volume of the silica. The $V_{\text {voids }}$ is the volume of the particle minus the volume of the solid silica:

$$
V_{\text {voids }}=\frac{\pi}{6}\left(x_{p}^{3}-m \frac{\rho}{\rho_{s}} x^{3}\right)
$$

where $x_{p}$ is the particle (xerogel or hydrogel) diameter. Combining Eqs. (8) and (9) and rearranging provides the following equation for internal particle voidage:

$$
\varepsilon_{s}=1-\frac{\rho}{\rho_{s}} m\left(\frac{x}{x_{p}}\right)^{3}
$$

Fig. 5 provides values for the ratio of the particle size and droplet size for both hydrogel and xerogel particles. Using the ratios shown in the figure provides internal particle voidages of $88 \%$ and $64 \%$ for the hydrogel and xerogel particles, respectively. The latter compares favourably with the value of $63 \%$ obtained from the pore volume and density determination.

For comparison, Chen et al. ${ }^{10}$ used an approach similar to Caroll et al. ${ }^{11}$ (acidified TEOS as silica source, surfactant templating method in a microfluidic device) and determined the internal surface area of the produced silica particles to be $550-675 \mathrm{~m}^{2} \mathrm{~g}^{-1}$ with the reported cumulative pore volume to be 1.1-2.6 $\mathrm{cm}^{3} \mathrm{~g}^{-1}$, depending on experimental parameters. Chokkalingam et al. ${ }^{12}$ (acidified TMOS with 
ammonia as silica source, sol-gel method, microfluidic co-flow device) produced silica particles with internal surface area of $820 \mathrm{~m}^{2} \mathrm{~g}^{-1}$ and the total reported pore volume of $0.93 \mathrm{~cm}^{3} \mathrm{~g}^{-1}$. The highest pore volume created in this work measured by BET was $0.88 \mathrm{~cm}^{3} \mathrm{~g}^{-1}\left( \pm 0.03 \mathrm{~cm}^{3} \mathrm{~g}^{-1}\right)$ and calculated from Eq. 8 and a material balance was found to be $0.86 \mathrm{~cm}^{3} \mathrm{~g}^{-1}$. However, to date, no membrane emulsification synthesis route has been reported for the production of porous silica particles larger than $5 \mu \mathrm{m}$. The increase in pore size, in the case of the sample aged in acetone and produced from the solution with higher $\mathrm{pH}$ (4.5), may be interpreted in two ways.

When silica particles are prepared from sodium silicate $\left(\mathrm{Na}_{2} \mathrm{SiO}_{3}\right)$ it is necessary to add acid (sulfuric, hydrochloric, etc.) in order to create silicic acid $\left(\mathrm{Si}(\mathrm{OH})_{4}\right)$ as shown by equation (5). The silicic acid rapidly dimerises with elimination of water and then with further elimination of water forms trimers and in this way eventually polymerizes. The polymer continues to grow forming polymer aggregate spheres a few Angstrom in diameter. When the spheres reach a particular size, the surface hydroxyl groups from different spheres condense forming a gel. The porosity and surface area of the subsequent silica gel is determined by the size of these spheres which will depend on the conditions of formation and on the manner in which the gel is subsequently washed. According to $\mathrm{Iler}^{1}$, the increase of the $\mathrm{pH}$ increases the size of the primary silica particles too. Through the condensation polymerization reaction, particles come together to form the gel structure, so when bigger particles solidify they form the less dense gel structure with larger pores. The xerogel structure is a collapsed and distorted version of the structure that originally existed at the gel point. During the drying stage, the gel shrinks and the capillary force, which is directly proportional to the capillary pressure $p_{c}$, exerted on the network depends on the surface tension of the liquid $\varphi$, contact angle $\theta$, and the pore size $R$ :

$$
p_{c}=2 \varphi \cos (\theta) / R
$$

Since the pore size can be very small the capillary pressure, which collapses the initial gel structure can be enormous ${ }^{1}$. By using acetone during the drying step, which has a 3 times lower surface tension than water, the capillary pressure is lower, hence the gel shrinks less and larger pores are created. Aging 
silica hydrogels due to continued condensation polymerization has also been reported ${ }^{42}$, where other details of the influence of washing and aging on pore structure are recorded.

\section{Conclusions}

Spherical silica particles with mean particle sizes controllable within a range between 30 and $70 \mu \mathrm{m}$ have been produced from inexpensive sodium silicate solution. It was possible to control the internal structure, i.e. pore diameters and voidage, by an aging process of the particles in different solvents from which the final, xerogel, particles were produced. The starting point for the different techniques was membrane emulsification: injecting the aqueous phase into an oil phase, kerosene, containing a surfactant to stabilize the droplets. Careful control of the stirring, after droplet formation, was required in order to maintain the spherical shape and to avoid droplet damage by the stirrer. Likewise, careful control of the $\mathrm{pH}$ of the aqueous phase being injected was required, as it controlled the rate of polymerization: too high $\mathrm{pH}$ and the reaction was too fast risking blockage within the membrane emulsification equipment, and too low $\mathrm{pH}$ led to long polymerization times and, therefore, long stirring times where damage to the gelling particles was more likely to occur. Hence, the optimum $\mathrm{pH}$ for the process was determined to be 3.5 .

A coefficient of variation of the particle sizes formed of less than $20 \%$ was possible. This is a higher value than techniques where a single, or few, pores or channels are active in the production of the liquid droplets, but the productivity of the process described here is much higher and scalable to much larger areas of membrane. Also, normally, it is difficult to produce near-monosized silica particles in the range between 20 and $100 \mu \mathrm{m}$, which is a size range of relevance to industrial applications of process-scale column operation and catalysis. There appears to be no pre-existing literature on membrane emulsification for this size of silica particles. Scaling up to larger productivity is possible by altering the means by which the shear is generated on the surface of the membrane: a system that oscillates the membrane to generate the shear has been recommended for such use, and for another liquid system the 
droplet size results were found to be comparable ${ }^{18}$ between the two techniques: Dispersion Cell and oscillating membrane.

The BET pore size analysis indicated that the internal porosity, or voidage, of the particles produced was between $47 \%$ and $64 \%$, depending on the solvent used for aging. A material balance based on the known starting mass of silica present and an analysis of the droplet and final (xerogel) particle size provided a very similar result for internal porosity, for all the different sizes of particles produced. The internal porosity of the hydrogel particles was close to $90 \%$, and the shrinkage of the droplets as they changed from liquid to hydrogel, and then xerogel, was monitored by microscope analysis and confirmed the progression of the polymerization from liquid droplets, to hydrogel and then xerogel, where the xerogel size mass balance provided an internal voidage equal to the BET value. There was no further shrinkage between the air dried xerogel and the calcined particles that were used for the BET analysis. The particles produced in this work could be suitable for use as supports of functional groups for selective separations of components within liquids ${ }^{2}$.

\section{Acknowledgements}

The authors wish to acknowledge the financial support of the UK Engineering and Physical Sciences Research Council. The work was undertaken as part of the DIAMOND project into Decommissioning, Immobilisation And Management Of Nuclear wastes for Disposal. 


\section{List of symbols}

CV coefficient of variation, -

D stirrer diameter, $\mathrm{m}$

$d \quad$ mean droplet diameter by volume, $\mathrm{m}$

$D_{m} \quad$ effective diameter of the membrane, $\mathrm{m}$

$k \quad$ fraction of active pores, -

$Q_{d} \quad$ volume flow rate of dispersed phase, $\mathrm{m}^{3} \mathrm{~s}^{-1}$

$m \quad$ mass fraction of silica present in the liquid, -

$N \quad$ total number of pores in membrane, -

$p_{c} \quad$ capillary pressure, $\mathrm{Pa}$

$r \quad$ distance from the membrane centre, $\mathrm{m}$

$R \quad$ pore size within the silica gel, $\mathrm{m}$

Re Reynolds number, -

$r_{p} \quad$ membrane pore radius, $\mathrm{m}$

$r_{\text {trans }} \quad$ transitional radius, $\mathrm{m}$

$T \quad$ tank diameter, $\mathrm{m}$

$t_{\text {neck }} \quad$ necking time, $\mathrm{s}$

$v_{\text {drop }} \quad$ volume of acidified sodium silicate droplet, $\mathrm{m}^{3}$ 
$\begin{array}{ll}v_{\text {part }} & \text { volume of silica particle, } \mathrm{m}^{3} \\ V & \text { droplet volume, } \mathrm{m}^{3} \\ V_{\text {crit }} & \text { droplet volume predicted with the model. } \mathrm{m}^{3} \\ V_{p} & \text { cumulative pore volume, } \mathrm{cm}^{3} \\ V_{\text {solid }} & \text { solid volume within the silica particle, } \mathrm{m}^{3} \\ V_{\text {voids }} & \text { void volume within the silica particle, } \mathrm{m}^{3} \\ x_{p} & \text { Diameter of xerogel or hydrogel particle, } \mathrm{m}\end{array}$

Greek symbols

$\rho \quad$ acidified sodium silicate solution density, $\mathrm{kg} \mathrm{m}^{-3}$

$\rho_{s} \quad$ solid silica density, $\mathrm{kg} \mathrm{m}^{-3}$

$\mu \quad$ dynamic viscosity of continuous phase, $\mathrm{Pa} \mathrm{S}$

$\gamma \quad$ interfacial tension, $\mathrm{N} \mathrm{m}^{-1}$

$\delta \quad$ boundary layer thickness, $\mathrm{m}$

$\varepsilon_{s} \quad$ internal particle voidage, -

$\theta \quad$ contact angle, -

$\sigma \quad$ standard deviation of droplet diameter, $\mathrm{m}$

$\tau_{a v} \quad$ average shear stress on membrane surface, $\mathrm{Pa}$ 
$\varphi \quad$ surface tension, $\mathrm{N} \mathrm{m}^{-1}$

$\omega$

angular velocity, $\mathrm{s}^{-1}$ 


\section{References}

(1) Iler, R.K. The chemistry of silica: solubility, polymerization, colloid and surface properties, and biochemistry, $1^{\text {st }}$ ed., Wiley: New York, 1979.

(2) Jal, P.K.; Patel, S.; Mishra, B.K. Talanta 2004, 62, 1005-1028.

(3) Buranda, T.; Huang, J.; Ramarao, G.V.; Linnea, K.; Larson, R.S.; Ward, T.L.; Sklar, L.A.; Lopez, G.P. Langmuir 2003, 19, 1654-1663.

(4) Ide, M.; Wallaert, E.; Van Driessche, I.; Lynen, F.; Sandra, P.; Van Der Voort, P. Micropor. Mesopor. Mat. 2011, 142, 282-291.

(5) Barbé, C.; Bartlett, J.; Kong, L.; Finnie, K.; Lin, H.Q.; Larkin, M.; Calleja, S.; Bush, A.; Calleja, G. Adv. Mat. 2004, 16,1959-1966.

(6) Suzuki, T.M.; Yamamoto, M.; Fukumoto, K.; Akimoto, Y.; Yano, K. J. Catal. 2007, 251, 249 257.

(7) Lin, H.P.; Mou, C.Y., Accounts Chem. Res. 2002, 35, 927-935.

(8) Titulaer M.K.; den Exter M.J.; Talsma H.; Jansen J.B.H.; Geus J.W. J Non-Cryst. Solids 1994, $170,113-127$.

(9) Andersson, N.; Kronberg, B.; Corkery, R.; Alberius, P. Langmuir 2007, 23, 1459-1464.

(10) Chen, Y.; Wang, Y.J.;Yang, L.M.; Luo, G.S. AICHE J. 2008, 54, 298-309.

(11) Carroll, N.J.; Rathod, S.B.; Derbins, E.; Mendez, S.; Weitz, D.A.; Petsev, D.N. Langmuir 2008, $24,658-661$.

(12) Chokkalingam, V.; Weidenhof, B.; Krämer, M.; Maier, W.F.; Herminghaus, S.; Seemann, R. Lab on a Chip 2010, 10, 1700-1705. 
(13) Kobayashi, I.; Nakajima, M.; Mukataka, S. Colloid. Surface. A 2003, 229, 33-41.

(14) Schröder V.; Behrend O.; Schubert H. J. Colloid Interf. Sci., 1998, 202, 334-340.

(15) Kosvintsev, S.R.; Gasparini, G.; Holdich, R.G. Cumming, I.W.; Stillwell, M.T., Ind. Eng. Chem. Res. 2005, 44, 9323-9330.

(16) Nakashima, T.; Shimizu, M.; Kukizaki, M. Key Eng. Mat. 1991, 61, 513-516.

(17) Vladisavljević, G.T.; Williams, R.A. J. Colloid Interf. Sci. 2006, 299, 396-402.

(18) Holdich, R.G.; Dragosavac, M.M.; Vladisavljevic, G.T.; Kosvintsev, S.R. Ind. Eng. Chem. Res. 2010, 49, 3810-3817.

(19) Joscelyne, S.M.; Trägårdh, G. J. Membrane Sci. 2000, 169, 107-117.

(20) Peng, S.; Williams, R.A. Part. Part. Syst. Char. 1998, 15, 21-25.

(21) Yanagishita, T.; Tomabechi, Y.; Nishio, K.; Masuda, H. Langmuir 2004, 20, 554-555.

(22) Hosoya, K.; Bendo, M.; Tanaka, N.; Watabe, Y.; Ikegami, T.; Minakuchi, H.; Nakanishi, K. Macromol. Mater. Eng. 2005, 290, 753-758.

(23) Kandori K.; Kishi K.; Ishikawa T. Colloid. Surface. 1992, 62, 259-262.

(24) Fuchigami T.; Toki M.; Nakanishi K. J. Sol-Gel Sci. Techn. 2000, 19, 337-341.

(25) Dragosavac, M.M.; Sovilj, M.N.; Kosvintsev, S.R.; Holdich, R.G.; Vladisavljević, G.T. J. Membrane Sci. 2008, 322, 178-188.

(26) Stillwell, M.T.; Holdich, R.G.; Kosvintsev, S.R.; Gasparini, G.; and Cumming I. W. Ind. Eng. Chem. Res., 2007, 46, 965-972.

(27) Holdich, R.G.; Cumming, I.W.; Kosvintsev, S.; Bromley, A.J.; Stefanini, G. Miner. Eng., 2003, $16,121-128$. 
(28) Yilmaz, I. I.; Holdich, R. G.; Kabay, N.; Bryjak, M.; Yuksel, M. React. Funct. Polym. 2007, 67, $1628-1634$.

(29) Dragosavac M.M.; Holdich, R.G.; Vladisavljević, G.T. Ind. Eng. Chem. Res. 2011, 50, 24082417.

(30) Barret, E.P.; Joyner, L.G.; Halenda, P.P. AICHE J. 1951, 73, 373-380.

(31) Brunauer, S.; Emmett, P.H.; Teller, E. AICHE J. 1938, 60, 309-319.

(32) Egidi, E.; Gasparini, G.; Holdich, R.G.; Vladisavljević, G.T.; Kosvintsev, S.R. J. Membrane Sci. 2008, 323, 414-420.

(33) van der Graaf, S.; Steegmans, M.L.J.; van der Sman, R.G.M.; Schroën, C.G.P.H.; Boom, R.M. Colloid. Surface. A 2005, 266, 106-116.

(34) Vladisavljević, G.T.; Schubert, H. Desal. 2002, 144, 167-172.

(35) van der Graaf, S.; Schroën, C.G.P.H.; van der Sman, R.G.M.; Boom, R.M. J. Colloid Interf. Sci. 2004, 277, 456-463.

(36) Thompson K. L.; Armes S. P.; York D. W. Langmuir 2011, 27, 2357-2363.

(37) Muñoz-Aguado, M.J.; Gregorkiewitz, M.; Bermejo, F.J. J. Non-Cryst. Solids 1995, 189, 90-100.

(38) Dubinin, M.M. Adv. Colloid Interfac. 1968, 2, 217-235.

(39) Sing, K.S.W.; Everett, D.H.; Haul, R.A.W.; Moscou, L.; Pierotti, R.A.; Rouquerol, J.; Siemieniewska, T. Pure App. Chem. 1985, 57 (4), 603-619.

(40) Muñoz-Aguado, M.; Gregorkiewitz, M. J. Colloid Interf. Sci. 1997, 185 (2), 459-465.

(41) Gurav, J.L; Jung, I; Park, H.; Kang, E.S; Nadargi, D.Y. Journal of Nanomaterials, vol. 2010, Article ID 409310, 11 pages, 2010. doi:10.1155/2010/409310. 
(42) Sarawade, P.B.; Kim, J.; Hilonga, A.; Quang, D.V.; Kim, H.T. Microporous and Mesoporous Materials. 2011, 139, 138-147. 
Table of Contents Graphic

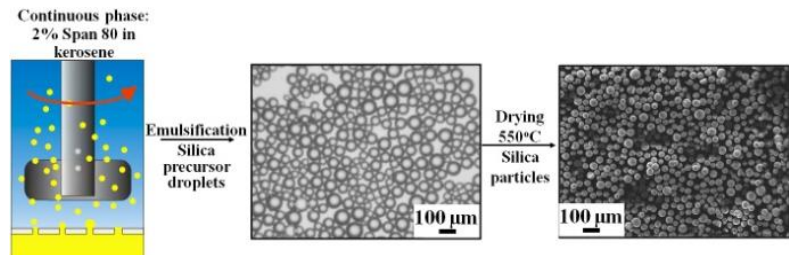

Dispersed phase:

$\mathrm{pH}=3.5$ 